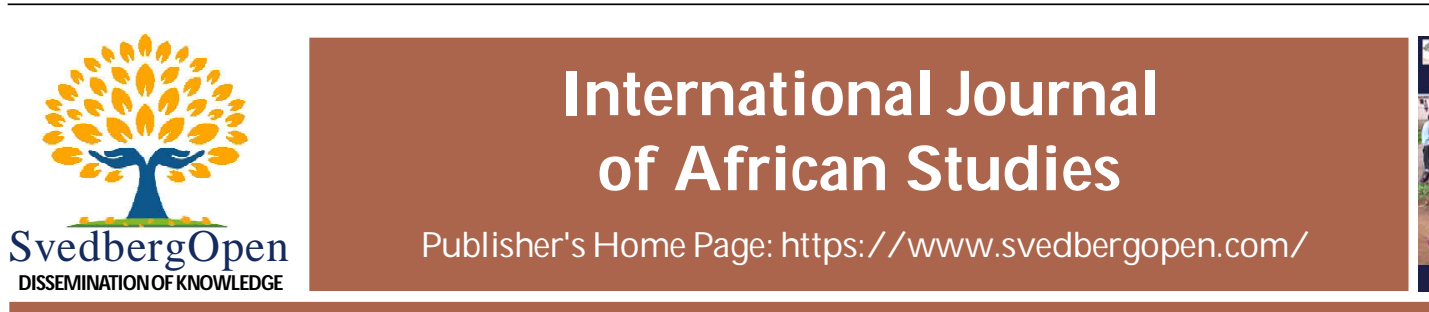

Research Paper

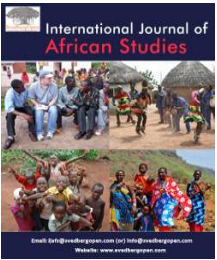

Open A ccess

\title{
The International criminal court in Africa: A motion for continued constructive engagement
}

George Shadrack Kamanda ${ }^{1^{*}}$

${ }^{1}$ J.D. Candidate, 2022, Case Western Reserve University, School of Law. E-mail: kamanda_g@yahoo.com

\section{Article Info}

Volume 1, Issue 2, June 2021

Received : 02 January 2021

Accepted : 10 April 2021

Published : 05 June 2021

doi: 10.51483/IJAFRS.1.2.2021.27-42

\section{Introduction}

This paper examines the ongoing tension between African countries and the International Criminal Court (ICC) that have led Africans, mainly African leaders believing the ICC to be an anti-Africa institution. ${ }^{1}$ The examination of strained

\begin{abstract}
In the last decade, African states and their leaders have levied heavy criticisms against the International Criminal Court (ICC) operations on the continent. The ICC has been accused of infringing states sovereignty, engaging in selective justice and serving as an instrument for furthering neocolonialism. This paper examines Africa's criticisms of the Court in detail and advances ways to improve relations between African states and the ICC. The examination of the strained relationship between Africa and the ICC will start with a survey of Africa's criticisms against the ICC, followed by brief background information into the nature of crimes and other human rights violations taking place on the African continent. Crimes committed on the continent are analyzed for context and relevance; however, the nucleus of the paper will focus on refuting Africa's criticisms of the ICC as an anti-Africa institution. Next, the paper engages in a substantive legal analysis of ICC's law and procedures by providing counterargument responses to Africa's criticisms. Furthermore, a motion supporting ICC's relations on the continent is advanced to rebuild and reform for continued constructive engagement between African states and the ICC. The paper concludes that Africa's criticisms of the ICC are more political than legal and, as a result, urges all parties and actors involved to foster a path for continued constructive engagement as a means to remedy the ongoing tension between African states and the ICC.
\end{abstract}

Keywords: Africa, International Criminal Court, African Union, Rome Statute, engagement, African states, reforms

(C) 2021 George Shadrack Kamanda. This is an open access article under the CC BY license (https://creativecommons.org/licenses/by/4.0/), which permits unrestricted use, distribution, and reproduction in any medium, provided you give appropriate credit to the original author(s) and the source, provide a link to the Creative Commons license, and indicate if changes were made.

Karen Allen. Is This the End for the International Criminal Court? BBC. October 24, 2016. This article by the BBC provides a detailed outlook the ICC's role in Africa as well as address the different anti-Africa criticisms levied against the ICC. https:// www.bbc.com/news/world-africa-37750978

CNN. International Criminal Court Fast Facts. CNN Editorial Research. Updated on November 11, 2019). There are uncontested documentation of the heinous crimes and other human rights violations committed on the African continent over the years are general or public knowledge. See a CNN's detailed report of some of the African case before the court and how and what led to the charges being brought against the African leaders and war lords from African countries listed below. https://www.cnn.com/2016/07/ 18/world/international-criminal-court-fast-facts/index.html See also Abdul Tejan-Cole, a former prosecutor at the Special Court for Sierra Leone take on whether Africa is on trial. In his view, the ICC is in no way targeting Africa unfairly and calls African leaders stop politicizing the situation. https://www.bbc.com/news/world-africa-17513065 Generally known, countries like Kenya, Sudan, Democratic Republic of Congo, Ivory Coast, Mali, Uganda, Libya, Central African Republic, Burundi, Nigeria and recently, South Africa have all had cases and ongoing situations under the ICC's jurisdiction. See the ICC's list of situations and cases here: https:/ /www.icc cpi.int/Pages/cases.aspx\#Default =\%7B \%22k\%22\%3A\%22\%22\%7D\#2ae8b286-eb20-4b32-8076-17d2a9d9a00e=\%7 B $\% 22 \mathrm{k} \% 22 \% 3 \mathrm{~A} \% 22 \% 22 \% 7 \mathrm{D}$

* Corresponding author: George Shadrack Kamanda, J.D. Candidate, 2022, Case Western Reserve University, School of Law. E-mail: kamanda_g@yahoo.com

2710-4680/@ 2021. George Shadrack Kamanda. This is an open access article distributed under the Creative Commons Attribution License, which permits unrestricted use, distribution, and reproduction in any medium, provided the original work is properly cited. 
relationship between Africa and the ICC will start with a survey of Africa's criticisms against the ICC. Here, a brief background information into the nature of crimes and other human rights violations taking place on the African continent will be examined. ${ }^{2}$ This paper will reference crimes committed on the continent for context and relevance; however, the nucleus of the paper will focus on refuting Africa's criticisms of the ICC as an anti-Africa institution. Next, this paper will forward a motion to help foster a receptive environment for the continued constructive engagement between the African state and the ICC.

Part II examines the factual background of the formation of the ICC, and Africa's role in the signing and ratification of Rome Statute that helped in the establishment of the ICC. This part further surveys Africa's pioneering early relationship with the ICC and the roles played by African civil society groups in bring to existence what is known today as the world's court (ICC). Part III examines Africa's criticisms against the ICC. Many critics, especially African leaders and politicians have labeled the ICC to be an Anti-Africa institution, whose actions of prosecuting leaders of the continent are a threat to peace and its justice rationale has been one of selective justice. Part IV - the heart of this paper engages in a substantive legal analysis by providing counter argument responses to Africa's criticisms of the ICC. In responding to Africa's criticisms, a survey of relevant ICC's laws and procedures involved in trying a case will be examined.

Part V will put forward recommendations for all actors involved to build and foster an atmosphere receptive for continued constructive engagement between African states and the ICC. Actors such as the United Nations Security Council (UNSC), the African Union (AU), African member states and other state parties to the ICC must build bridges and work towards the effective maintenance, prevention and protection of the values of the rule of law and international justice. Part VI will conclude by summarizing the nuanced perspectives highlighted in this paper. This paper concludes that Africa's criticisms of the ICC are more political than legal and as result, urges all parties and actors involved to foster a path for continued constructive engagement as a means to remedy the ongoing tension between African states and the ICC

\section{Factual background}

\subsection{African states and the signing of the Rome Statute}

History's first ICC was the Nuremberg Tribunal, created by the victorious allies after World War II to prosecute the major German war criminals. ${ }^{3}$ Despite the passage of time, the events that prompted the formation of the Nuremberg Tribunal in 1945 are probably more familiar to most than those which led to the creation of the ad hoc tribunals and the ICC at the end of the Twentieth century. ${ }^{4}$ The ICC was established on July 17, 1998 through a treaty signed in Rome by 120 states. ${ }^{5}$ The Court's mandate is to try those responsible for war crimes, genocide, crimes against humanity and crimes against aggression. ${ }^{6}$ African countries were early, enthusiastic supporters of the ICC ${ }^{7}$. The same is to be said of African individuals and civil society groups on the continent. The Organization of African Unity (OAU) (now the AU) has issued a number of resolutions and declarations supporting the establishment of the ICC and encouraging member states to ratify the Rome Statute ${ }^{8}$. Senegal became the first country in the world to ratify the Statute on February 2, 1999 and they were followed by several African countries in large numbers to form the largest block of the ICC's membership. ${ }^{9}$ As of this writing, there are thirty-three (33) African countries of the total 122 states parties to the Rome Statute. ${ }^{10}$

\subsection{Africa's early relationship with the ICC}

To understand the tension between the ICC and Africa, a brief examination of the cooperative early relationship is both relevant and invaluable. African states were instrumental in pushing for the realization of the ICC, ${ }^{11}$ and this is reflected

\footnotetext{
David M. Crane, Leilan N. Sadat and Michael Scharf. The Founder: Four Pioneering Individuals Who Launched the First ModernEra International Criminal Tribunals. Cambridge University Press, 32 (2018). Chapter II, by Michael Scharf titled 'The Cornerstone': Robert H Jackson and the Nuremberg Tribunal traces the history and the events that led to the establishment of the international courts and tribunals to fight and prevent heinous crimes in the world. One of these courts of invaluable significance today that came to be known as the International Criminal Court (ICC) founded in 2002 after several nations signed and ratified the Rome Statute effectively establishing the Court. Id.

5 Brendon J. Cannon, Dominic R. Pkalya, Bosire Maragia (2017). The International Criminal Court and Africa: Contextualizing the Anti-ICC Narrative. 6 (2017). file:///Users/shadrack/Downloads/TheInternationalCriminalCourtandAfrica\%20(1).pdf

6 Rowland J.V. Cole. (2014). Africa's relationship with the international criminal court: More political than legal. Melbourne Journal of International Law. 671 (2014). http://www.austlii.edu.au/au/journals/MelbJIL/2013/21.pdf

7 Hanibal Goitom (2016). The international criminal court and Africa. Library of Congress Blogs, November 23, 2016. https:// blogs.loc.gov/law/2016/11/falqs-the-international-criminal-court-and-africa/ Id.

Id.

Id.

Id. at 6
} 
in the fact that Africa has the highest regional representation to the Rome Statute. ${ }^{12}$ In joining this new found hope for global justice, countries joining "believed that global justice would benefit them as well as bring a semblance of an international body that can bring justice for the victims and prosecution for the perpetrators guilty of gross atrocities and human rights violations..."13 For Africa, the carnage the gripped Rwanda in 1994, now known as the Rwandan genocide and the need to find ways to prevent powerful countries from preying on weaker ones are generally known to be two most important reasons for joining the ICC. At the time of the signing of the Rome Statute, thus establishing the ICC, African states made up the majority of the signatories to the Court's jurisdiction. ${ }^{14}$ Even after Burundi's exit from the ICC, ${ }^{15}$ leaving thirty-three (33) African states remains the ICC's majority regional block. Criticisms levied against the ICC by critics, mostly African politicians and leaders has led to a strained or impaired working relationship.

\section{Africa's criticisms of the ICC}

\subsection{The anti-Africa narrative}

Majority of African leaders and politicians have branded the ICC as an anti-Africa institution because of the ICC's focused on crimes committed on the continent as opposed to other regions of the world. The Office of the Prosecutor (OTP) has sought to bring charges against 31 individuals since the ICC began operating in 2002_ all of them African. ${ }^{16}$ Kenya's President, Uhuru Kenyatta in 2013 lamented that "the court was race hunting on behalf of its benefactors and being used as a tool to oppress Africans ${ }^{17}$. President Kenyatta furthered his harsh criticisms stating that "Africa is not a third-rate territory of second-class peoples, we are not a project, or experiment of outsiders." 18 The AU and other African leaders have also weighed in on the anti-Africa sentiment allegations. Jean Ping, former President of the African Union Commission has slammed that, "we are not against the ICC, but there are two systems of measurement... [T] he ICC seems to exist solely for judging Africans." ${ }^{19}$ Since its creation in 1998, the ICC has been hobbled by the refusal of major countries like the United States, China and Russia to subject themselves to its jurisdiction. ${ }^{20}$ Based on this rationale, African critics of the ICC have relentlessly argued that such refusals from major countries supports their criticisms of the ICC. For their part, major powers like the United States, Russia and China are shielded from prosecution because they reject the court's jurisdiction over them and can veto any referral to the ICC by the UNSC. ${ }^{21}$ Yet nonparties to the court (ICC) have sometimes encouraged it to intervene in countries that also refuse to recognize its jurisdiction. ${ }^{22}$ Sudan and Libya present us a perfect example of this conundrum. At the time when the ICC indicted President Omar Hassan al-Bashir of Sudan and Col. Muammar el- Qaddafi of Libya at the request of the UNSC, neither countries where state parties to the ICC. ${ }^{23}$ The United States, China and Russia either voted for those referrals or abstained: considering their own rejection of the ICC's authority over them, their decision not to veto the referrals can only be seen as a tacitas well as opportunistic and hypocritical - endorsement of the cases. ${ }^{24}$ Clearly, recent withdrawal from Burundi, and reconsiderations of withdrawal by Gambia and South Africa "on grounds that the court is biased and undermines peace, seem like an unprecedented blow to its legitimacy." ${ }^{25}$ While cases and situations from other regions and countries in the

12 ICC. The States parties to the Rome Statute. https://asp.icc- See also Currently, 122 countries are States Parties to the Rome Statute of the International Criminal Court. Out of them 33 are African States, 18 are Asia-Pacific States, 18 are from Eastern Europe, 28 are from Latin American and Caribbean States, and 25 are from Western European and other States: International Criminal Court, The States Parties to the Rome Statute. https://asp.icc-cpi.int/en_menus/asp/states\%20parties/pages/the\%20states\%20 parties\%20to\%20the $\% 20$ rome\%20statute.aspx

13 Id.

$14 \quad I d$.

15 BBC. Burundi leaves International Criminal Court amid row. October 2, 2017. (last accessed November 3, 2019) https://www.bbc.com/ news/world-africa-41775951

16 Thierry Cruvellier. The ICC, Out of Africa. The New York Times, November 6, 2016. https://www.nytimes.com/2016/11/07/ opinion/the-icc-out-of-africa.html

17 Dickens Olewe. How Kenyatta led Africa's Opposition to the ICC. BBC. October 24, 2016. https://www.bbc.com/news/world-africa37750978

$18 \quad I d$.

19 Abreha, Mesele. (2019). International criminal court and african union: Selective justice? Abyssinia Law, June 17 (last accessed November 3, 2019) https://www.abyssinialaw.com/blog-posts/item/1513-international-criminal-court-and-african-union-selectivejustice

$20 \quad I d$. at 17.

${ }^{21} \quad I d$.

22 Id.

23 Id. at 14. Neither Sudan nor Libya is a party to the ICC; and in both cases, jurisdiction was granted through a United Nations Security Council resolution. (The United States abstained from the former Security Council vote, in 2005, and voted in favor of the latter, in February 2011.). See also https://www.everycrsreport.com/reports/RL34665.html. The UN Security Council made its first referral in 2005, for alleged crimes in the Darfur region of Sudan. This was followed in 2011 by a referral for Libya. See https:// www.cfr.org/backgrounder/role-international-criminal-court

24 Id. at 20.

25 Id. 
world have been investigated and under preliminary examinations ${ }^{26}$, however, the stained and perception of African critics of the ICC as a biased institution remain ${ }^{27}$. Still, today, cases from the African continent make up the majority of the ICC's caseload. These cases originated from Central Africa Republic (CAR), ${ }^{28}$ Kenya, ${ }^{29}$ Côte d'Ivoire, ${ }^{30}$ Libya,${ }^{31}$ the Democratic Republic of Congo, ${ }^{32}$ Sudan, ${ }^{33}$ and Uganda. ${ }^{34}$ These cases share two commonalities: One, all of the cases are from African and two, all the perpetrators or alleged wrongdoers invoked the anti-Africa sentiment as a defense. The Chairman of the AU Commission accused the OTP of African bias, exclaiming, "Why not Argentina? Why not Myanmar...Why not Iraq?" 35 African leaders have not hold back on venting their frustrations with the ICC. Rwandan President Paul Kagame has dismissed the Court, saying it is created to prosecute African and others from poor countries. ${ }^{36}$ This perception is rife in the African circles especially among African leaders and politicians who felt the ICC and its OTP apparatus are fundamentally against the continent. Critics notes that the clear lack of prosecutions from other countries has weakened support for the ICC in African countries and given the impression that the ICC is partisan. ${ }^{37}$

\subsection{Selective justice and conspiracy theory}

African critics have also argued that the court (ICC) is part of a conspiracy against Africa. ${ }^{38}$ The AU and the African leadership have since accused the ICC for signaling out or targeting Africans. ${ }^{39}$ President Uhuru Kenyatta joined in the bashing of the ICC by calling it a "court a 'farcical pantomime' which was no longer a home of justice." ${ }^{40}$ What generated the loudest outcry from leaders in Africa were the prosecutions of two sitting heads of state: President Uhuru Kenyatta of Kenya, over election violence in 2007, and Mr. President Al Bashir of Sudan. ${ }^{41}$ The colonial past of the two countries constitutes fertile ground for infusing anticolonial narratives in relation to the ICC investigations. ${ }^{42}$ The case of Kenya reechoed this same sentiment of neocolonialism after its two then candidates, Uhuru Kenyatta and William Ruto were charged for inciting widespread violence following Kenya's post-elections in 2008. Over a period of two months, after the presidential elections of December 27, 2007, more than 1,000 people were killed and at least 700,000 were displaced. ${ }^{43}$ Both individuals denounced the court as a tool of western neocolonialism. Likewise, "once elected, they refused to cooperate with the ICC's investigation and, the court claims, "interfered" with it. ${ }^{44}$ The government of Kenya responded

26 ICC. Situation and Cases. November 3, 2019, https://www.icc-cpi.int/pages/pe.aspx. Preliminary examinations have been opened in ten other countries, including Afghanistan, Colombia, Myanmar, Ukraine, and Venezuela. See https://www.cfr.org/backgrounder/ role-international-criminal-court

$27 \quad$ Id.

28 Prosecutor v Bemba (Warrant of Arrest) (International Criminal Court, Pre-Trial Chamber III, Case No ICC-01/05-01/08, 23 May 2008); Prosecutor v Bemba (Warrant of Arrest Replacing the Warrant of Arrest Issued on 23 May 2008) (International Criminal Court, Pre- Trial Chamber III, Case No ICC-01/05-01/08, 10 June 2008).

29 Prosecutor v Ruto (Decision on the Prosecutor's Application for Summons to Appear) (International Criminal Court, Pre-Trial Chamber II, Case No ICC-01/09-01/11, 8 March 2011); Prosecutor v Muthaura (Decision on the Prosecutor's Application for Summonses to Appear) (International Criminal Court, Pre-Trial Chamber II, Case No ICC-01/09-02/11, 8 March 2011); The charges were later dropped: Prosecutor v Muthaura (Prosecution Notification of Withdrawal of the Charges) (International Criminal Court, Trial Chamber V, Case No ICC-01/09-02/11, 11 March 2013).

30 Situation in the Republic of Côte d'Ivoire (Warrant of Arrest for Laurent Gbagbo) (International Criminal Court, Pre-Trial Chamber III, Case No ICC-02/11, 23 November 2011); Prosecutor v Simone Gbagbo (Warrant of Arrest) (International Criminal Court, Pre-Trial Chamber III, Case No ICC-02/11-01/12, 29 February 2012).

31 Prosecutor v Gaddafi (Warrant of Arrest for Muammar Gaddafi) (International Criminal Court, Pre-Trial Chamber I, Case No ICC01/11-01/11, 27 June 2011). The arrest warrant against Muammar Gaddafi was terminated on 22 November 2011 following his death.

32 Prosecutor v Lubanga (Warrant of Arrest) (International Criminal Court, Pre-Trial Chamber I, Case No ICC-01/04-01/06, 10 February 2006); Prosecutor v Katanga (Decision on the Joinder of the Cases against Katanga and Chui) (International Criminal Court, Pre-Trial Chamber I, Case No ICC-01/04-01/07, 10 March 2008).

33 Prosecutor v Al Bashir (Second Warrant of Arrest) (International Criminal Court, Pre-Trial Chamber I, Case No ICC-02/05-01/09, 12 July 2010) ('Second Al Bashir Warrant').. A new arrest warrant was issued again in 2017 when President Al Bashir flew to South Africa for an AU Summit. However, the South African Government refused to arrest him citing conflict with international law, specially the head of state and diplomatic immunity doctrine.

34 Situation in Uganda (Amended Warrant of Arrest for Kony) (International Criminal Court, Pre-Trial Chamber II, Case No ICC-02/ 04-01/05, 27 September 2005).

35 Fatou Bensouda. Africa Question: Is the (ICC (International Criminal Court)) Targeting Africa Inappropriately? ICC Forum. (accessed November 22, 2019), https://iccforum.com/africa

36 Id.

${ }^{37} \quad I d$.

38 Mark Kersten. Building Bridges and Reaching Compromise: Constructive Engagement in the Africa - ICC Relationship. Wayamo Foundation. Wayamo Foundation Policy Report 2018, 7; 5-25, (accessed November 5, 2019). https://www.wayamo.com/wpcontent/uploads/2018/05/ICC-Africa-Paper_May-2018-1.pdf

39 Id. at 11.

40 Id. at 1 .

41 Somini Sengupta. As 3 African Nations Vow to Exit, International Court Faces its own Trial. October 26, 2016. https:// www.nytimes.com/2016/10/27/world/africa/africa-international-criminal-court.html

42 Mattia, Cacciatori. (2018). When kings are criminals: Lessons from ICC prosecutions of African presidents. International Journal of Transitional Justice, 12(3), 394. October 29, https://doi.org/10.1093/ijtj/ijy023

43 Id.

44 Id. at 16. 
by challenging the cases and attacking the court. These efforts significantly—and ultimately successfully—undermined both prosecutions. ${ }^{45}$ The case against Kenyatta was dismissed in December 2014 on what the ICC Prosecutor called "a dark day for international criminal justice." ${ }^{46}$ The case against William Ruto was dismissed on April 5, 2016. ${ }^{47}$ Kenya's government in recent times have tightened its grip on the public press." ${ }^{48}$ In 2014 , the government passed the Security Laws Amendment Act, which allows for long prison sentences and fines for the unauthorized reporting of information that undermines counterterrorism investigations. ${ }^{49}$

Another case study of delaying tactics against ICC prosecution is Sudan, where the government, aided by other African countries and the AU, shielded President Al Bashir from prosecution. Al Bashir from prosecution. The March 4, 2009, issuance of an arrest warrant for Omar Hassan Ahmad Al Bashir, the incumbent president of Sudan, a country that is not a state party to the Rome Statute, is said to have caused the relationship to sour. ${ }^{50} \mathrm{Al}$ Bashir's indictment was based, as stipulated under art. 13(b) of the Rome Statute ${ }^{51}$ on a 2005 UNSC resolution referring the Darfur conflict to the ICC. ${ }^{52}$ The rift grew with the indictment of the former Libyan President, Muammar Gaddafi, also through a UNSC referral, and the Kenyan President, Uhuru Kenyatta, and his deputy, William Ruto. ${ }^{53}$ Following the first arrest warrant of $\mathrm{Al}$ Bashir, the AU issued and endorsed a communique rallying in defense of ending impunity in Africa, but going a step further to express the necessity of conducting international justice in a "transparent and fair manner, in order to avoid any perception of double standard." ${ }^{54}$ After the AU made several unsuccessful request to defer proceedings to the UNSC, it then went on to urge its members to not cooperate with the ICC. In its $142^{\mathrm{ND}}$ Communique, ${ }^{55}$ the AU stated:

in view of the fact that the request by the AU [to the UNSC to defer the proceedings initiated against President Bashir] has never been acted upon, the AU Member States not cooperate pursuant to the provisions of Article 98 of the Rome Statute of the ICC relating to immunities, for the arrest and surrender of President Omar El Bashir of The Sudan.

Since President Al Bashir indictment, he has visited a number of African states that are signatories to the Rome Statute, including Chad, Democratic Republic of Congo, Kenya, South Africa and Uganda, all of which ignored their obligation to enforce the arrest warrant. ${ }^{56}$ Clearly, the AU has been flexing its power to affect its member states to act contrary to their obligation under the Rome Statute. Several years later, after Al Bashir's indictment, the AU has made decisions by issuing communiques on key issues that either sought cooperation with or confronted the ICC and the UNSC actions in Africa. These challenges are clearly noted in its October 12, 2013 decisions and declarations sessions held in its head quarter, Addis Ababa, Ethiopia. ${ }^{57}$ First, the declarations called for the amendment of Article 16 of the Rome Statute to empower the UN General Assembly to act in instances where the UNSC fails to decide on a deferral request. Second, a do-not-cooperate instructions to its member states against ICC's warrants. Third, a decision to end the practice of commencing or continuing cases against sitting heads of states, and fourth, the declarations call for an urgent development on a comprehensive strategy including collective withdrawal from the ICC. ${ }^{58}$

President Bashir has first of two separate arrest warrants, with the first released on March 4, 2009, charging Al Bashir with seven counts of war crimes and crimes against humanity, making the Sudanese president the first setting head of state to be indicted. ${ }^{59}$ President Bashir's second arrest warrant came in 2010 and this time he faced charges

45 Laurence, R. Helfer, Anne, E., Showalter. (2017). Opposing International Justice: Kenya's Integrated Backlash Strategy Against the ICC. iCourts Working Paper Series, No. 83, 2017. (accessed November 22, 2019) https://scholarship.law.duke.edu/cgi/ viewcontent.cgi article $=6404 \&$ context=faculty_scholarship

46 Statement of the Prosecutor of the International Criminal Court, Fatou Bensouda, on the Withdrawal of Charges Against Mr. Uhuru Muigai Kenyatta (Dec. 5, 2014), https://www.icc-cpi.int/Pages/item.aspx?name=Adjourn-Kenyatta.

47 Prosecutor v. William Samoei Ruto and Joshua Arap Sang, Decision on Defence Applications for Judgments of Acquittal, ICC-01/ 09-01/11 (April 5, 2016), https://www.icc-cpi.int/CourtRecords/CR2016_02617.pdf

48 Id. at 43.

49 Id. See also Freedom House, 'Kenya,' 10 March 2016, https://freedomhouse.org/report/freedom-press/2016/kenya (accessed November 22, 2019)

50 Id. at 10 .

Rome Statute Article 13 (b).

Id. at 50

$53 \quad$ Id.

54 African Union. Communique of the 142nd Meeting of the Peace and Security Council. PSC/MIN/Comm (CXLII) July 21 , 2008. (accessed November 22, 2019) http://www.iccnow.org/documents/AU_142-communique-eng.pdf

$55 \quad I d$.

$56 \quad$ Id. at 53 .

57 African Union. Extraordinary Session of the Assembly of the African Union: Decisions and Declarations. October 12, 2013, (accessed November 22, 2019). http://www.iccnow.org/documents/Ext_Assembly_AU_Dec_Decl_12Oct2013.pdf

58 Id. See also. Hanibal Goitom's article on Africa's relationship with the ICC. https://blogs.loc.gov/law/2016/11/falqs-the-internationalcriminal-court-and-africa/

$59 \quad$ Id. at 48. 
of genocide ${ }^{60}$ for crimes in the Darfur region. As was in Kenya, public press freedom and other citizens' rights were significantly restraint by the Sudanese government after both arrest warrants. In 2009, the Sudanese government passed the Press and Publications Act, which allows for press restrictions in the interests of national security ${ }^{61}$ According to the Non-Governmental Organization (NGO) Freedom House, the 2015 Freedom of Information Law includes 12 categories of exemptions to protect information from public release. ${ }^{62}$ The Press and Publications Act is a problematic piece of Sudanese legislation: though designed to protect and ensure the freedom of expression for journalists, the Act and its attendant Council, which is made up of $40 \%$ political detainees, has been used to press criminal charges against journalists and confiscate newspapers from printing houses. ${ }^{63}$ As a result, and of consequence, victims, especially lay citizens have been afraid to speak against the government or the crimes committed by the government in most instances. For example, the case of the editor of the socialist newspaper Al-Midan, who was wrongly charged in 2015 with offences including publishing false news offers a striking example of human rights violations in Sudan. ${ }^{64}$ Although she was eventually released on bail; if convicted, she would have faced capital punishment. ${ }^{65}$ This shows the heightened levels of restrictions of citizens human rights and freedom in an already violate country.

\subsection{Disrespect of African states sovereignty}

African leaders have lambasted the ICC of disrespect the sovereignty of African states and by extension, they argue, the blunt disregard of the norms of international politics and sovereign immunity. This is essentially the only legal claim African leaders and critics could make over the ICC interventions in Africa. According to Margaret M. DeGuzman, "critics charge the ICC with failing to respect the international law governing head of state immunity, which they claim prohibits prosecution of heads of state, even for international crimes." ${ }^{\prime 66}$ Critics have also accused the ICC of violating its own Statute regarding the admissibility of situation and cases. Again, DeGuzman confirmed that "in particular, they claimed that the ICC is not respecting the principle of complementarity, which prohibits the Court from investigating or prosecuting cases when a state with jurisdiction is doing so in good faith." ${ }^{67}$ Logically, there is insufficient evidence to support either of these claims against the ICC. In defense of the ICC, DeGuzman further endorsed that "although the legal requirements of admissibility and the law of immunity for non-parties remain unclear, the ICC has interpreted and applied them in a plausible fashion." ${ }^{6}$ The government of South Africa case and the Rwandan President response to ICC biased role on the continent are two examples were the ICC has been criticized for failing to respect African's states sovereignty.

South Africa was also implicated in the Al Bashir saga between the AU and the ICC. In its defense, the South African government had argued that international law granting immunity for sitting heads of state prevented it from arresting AlBashir and conflicted with the Rome Statute's obligations to arrest and surrender him to the ICC. ${ }^{69}$ Instead, it chose not to, facing a reprimand from its own justice system. ${ }^{70}$ Judges of the ICC ruled that South Africa failed to comply with its obligations by not arresting and surrendering Omar Al-Bashir to the Court while he was on South African territory between June 13 and 15, 2015. ${ }^{71}$ Presently, the government of South Africa is preparing to quit the ICC and also plans to introduce an alternative system for the prosecution of international crimes. ${ }^{72}$ The system for the prosecution of genocide, crimes against humanity and war crimes will come into effect once South Africa withdraws from the Rome Statute of the ICC. ${ }^{73}$ A case in point is that several countries in Africa has employed similar delaying strategy like the one employed by the South African government.

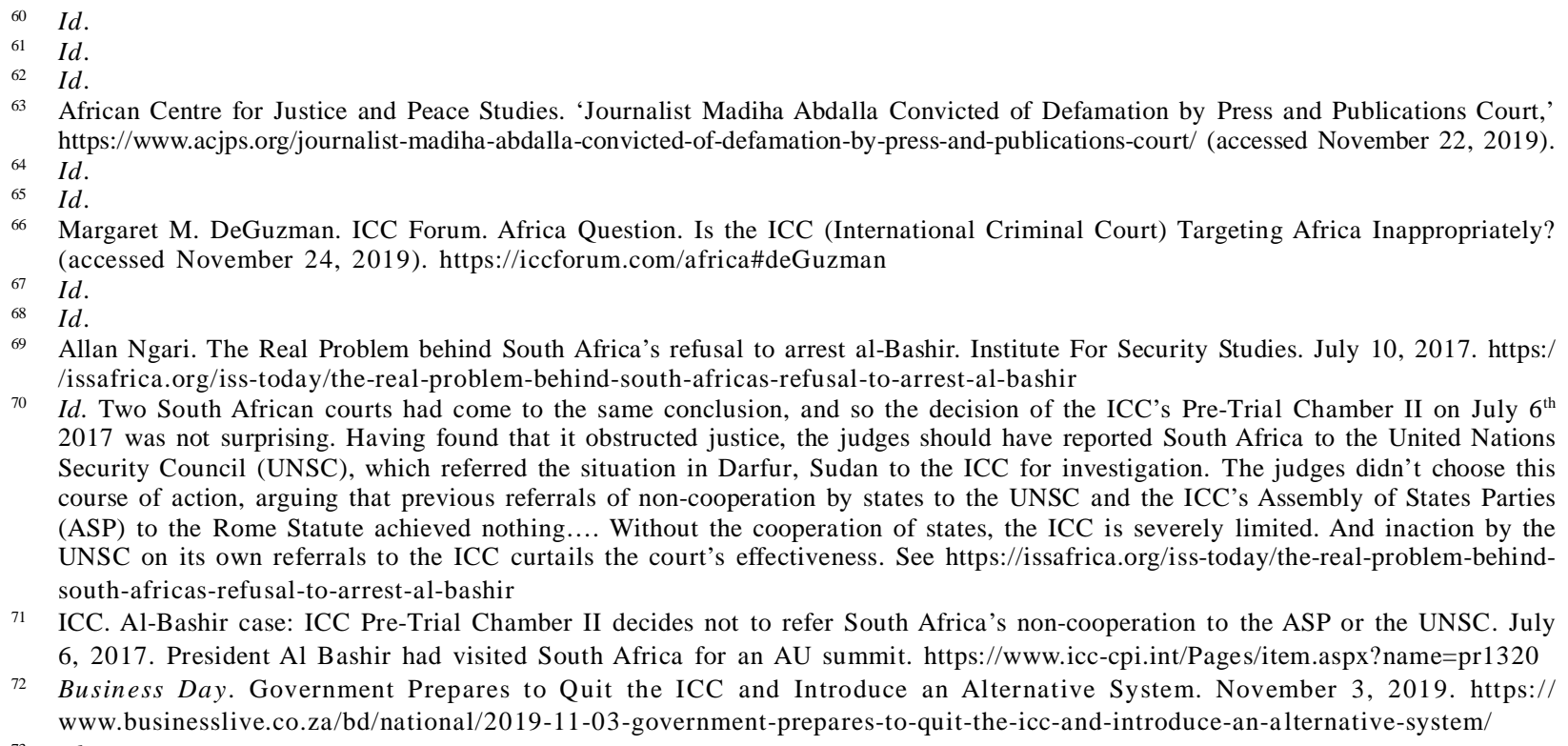

70 Id. Two South African courts had come to the same conclusion, and so the decision of the ICC's Pre-Trial Chamber II on July 6 $6^{\text {th }}$ 2017 was not surprising. Having found that it obstructed justice, the judges should have reported South Africa to the United Nations Security Council (UNSC), which referred the situation in Darfur, Sudan to the ICC for investigation. The judges didn't choose this course of action, arguing that previous referrals of non-cooperation by states to the UNSC and the ICC's Assembly of States Parties (ASP) to the Rome Statute achieved nothing.... Without the cooperation of states, the ICC is severely limited. And inaction by the UNSC on its own referrals to the ICC curtails the court's effectiveness. See https://issafrica.org/iss-today/the-real-problem-behindsouth-africas-refusal-to-arrest-al-bashir

71 ICC. Al-Bashir case: ICC Pre-Trial Chamber II decides not to refer South Africa's non-cooperation to the ASP or the UNSC. July 6, 2017. President Al Bashir had visited South Africa for an AU summit. https://www.icc-cpi.int/Pages/item.aspx?name=pr1320

72 Business Day. Government Prepares to Quit the ICC and Introduce an Alternative System. November 3, 2019. https:// www.businesslive.co.za/bd/national/2019-11-03-government-prepares-to-quit-the-icc-and-introduce-an-alternative-system/

$73 \quad I d$. 
In line with the view above, a perfect example lends itself to the Rwandan President Paul Kagame. President Kagame has repeated his harsh criticism of the ICC for what he calls open bias against Africa, saying it has failed to mete out justice in any other part of the world. ${ }^{74}$ Statements like these have been re-echoed by the AU and other African leaders. Jean Ping, former President of the AU Commission has slammed the Court noting that "International law should not be wielded as the big stick by strong nations used to pummel the weak ones ${ }^{75}$. We are against selective justice, "if we have to be fair, the Georgian president, who is being accused by Russia of genocide, must face similar justice." ${ }^{76}$ In the same vain, Thuli Madonsela, former South Africa's Anti-Corruption Chief, re-echoed the same contradiction stating that "not least the fact that the United States refuses to become a member or be bound by its rules." ${ }^{\text {"77 }}$ Mr. Madonsela went on to say "some of the world leaders are part of the judging but they're not bound by it." 78 Again, Mr. Madonsela argued that "it is like saying, I'll be the judge but me and my children will not be bound by it." "This is one reason Mr. Bashir's indictment alienated man African leaders. ${ }^{80}$

\subsection{ICC's prosecutions of leaders are a threat to peace}

The ICC in particular has been accused of singling out only African leaders for prosecution. ${ }^{81}$ Bringing perpetrators of conflicts to justice in Africa is not easy. The ICC's effects on peace, justice, and conflict processes are shaped, even determined, by who is targeted for prosecution - and who is not. ${ }^{82}$ The AU alleges that by prosecuting active players of ongoing or recently ended conflicts, the ICC risks prolonging or reigniting further conflict. ${ }^{83}$ Another conundrum, however with the AU's 'peace and justice' argument is that it typically assumes similar behavior irrespective of context, ${ }^{84}$ and key factors including: how the ICC intervenes, who the ICC targets and who it does not; and who the Court's work in specific context benefits and legitimates. ${ }^{85}$ The Kenya and Sudan case discussed above present a good case in point for Africa's criticisms against the ICC as an anti-peace agent. Without concrete evidence, however, the AU has constantly argued that the ICC prosecutions of African leaders pose significant risks to peace in countries engaged in war or other in fighting. Kenya presents itself as a perfect example of this diversionary strategy against the ICC. As Susanne Mueller notes, 'winning the election was part of a key defense strategy to undercut the ICC by seizing political power, flexing it to deflect the ICC, and opening up the possibility of not showing up for trial if all else failed. ${ }^{86}$ Scholars have argued that in fact, ICC's intervention in Africa has led more so to unity than separation. In the case of Kenya, as noted by Gabrielle Lynch and Misa Zgonec-Reozej, two associate fellows at Chatham House, "the investigation fueled the formation of the Jubilee Alliance between Kenyatta and Ruto for the 2013 elections." ${ }^{87}$ Also, Christine Bjork and Juanita Goebertus noted in their article that "winning the elections in this context meant also being able to derail the investigation. ${ }^{88}$ The point these scholars are making tend to show that ICC's interventions are forming unity not division on the continent. There are mixed feelings about the direction of each country, with some countries embracing the ICC and others looking outside of its jurisdiction. Uganda and Kenya have been making noises about pulling out, although other African states, including Nigeria, have opposed such a move... Gabon have asked the court this month to look into possible war crimes on its territory. ${ }^{89}$ At times, it can seem as though the ICC's work is beholden to political interests: when the interests of states point towards cooperation and engagement with the ICC, the Court's work will be supported; when state interests

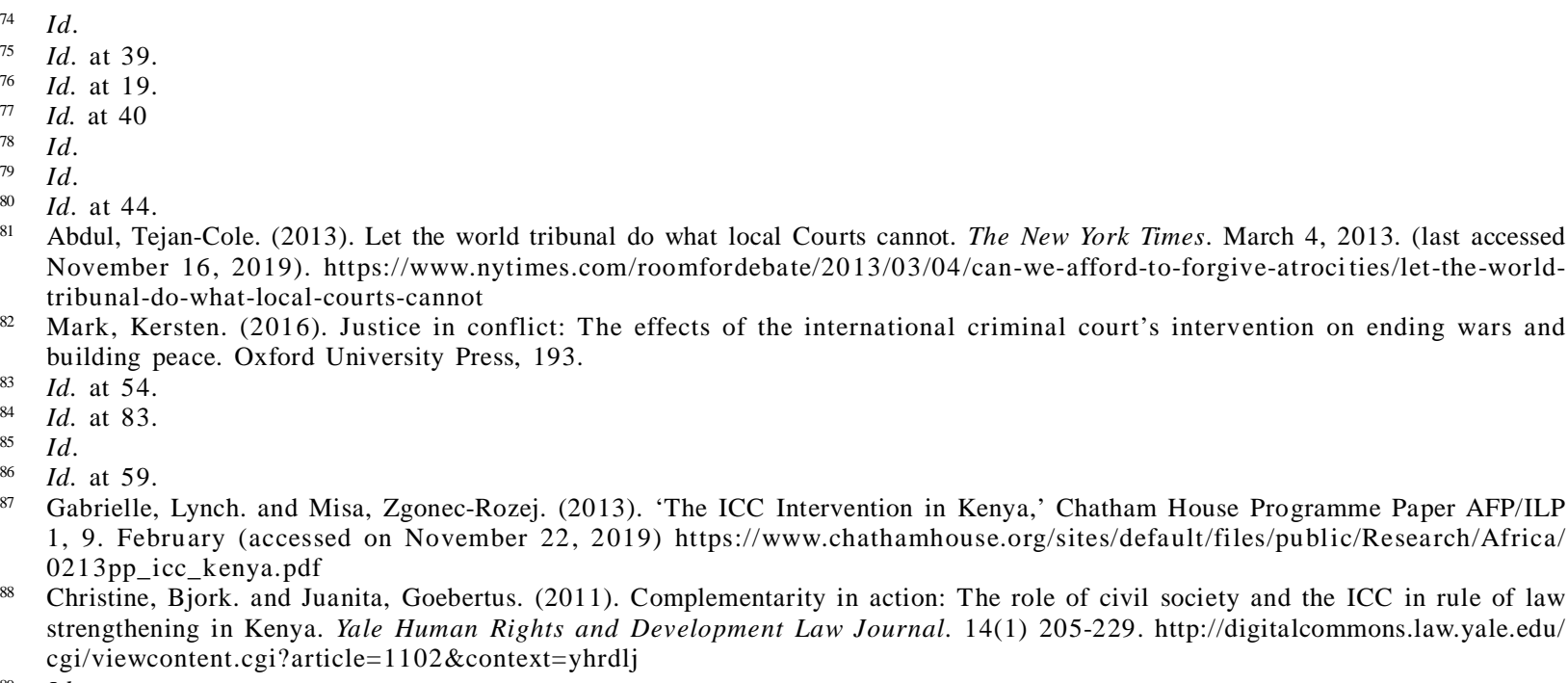

88 Christine, Bjork. and Juanita, Goebertus. (2011). Complementarity in action: The role of civil society and the ICC in rule of law strengthening in Kenya. Yale Human Rights and Development Law Journal. 14(1) 205-229. http://digitalcommons.law.yale.edu/ cgi/viewcontent.cgi article $=1102 \&$ context $=$ yhrdlj

$89 \quad I d$. 
are in conflict with the Court, the ICC's mandate will be undercut. ${ }^{90}$ As both the Kenya and Sudan case have shown us, African leaders criticisms of the ICC are informed by political and regional considerations rather than legal considerations. To survive this onslaught of criticism, "the [C]ourt must keep its distance from overt political machinations and avoid being instrumentalized or manipulated by state actors." 91

\section{Law and analysis: Response to Africa's criticisms}

The universality of ICC's membership is essential to the success of the ICC, but progress towards that goal is directly undermined when the ICC is perceived to be undermining the legitimate rights and prerogatives of states parties through jurisdictional overreach. ${ }^{92}$ In an ideal world, majority of African leaders and critics will subscribe to this rationale as a point to prove the ICC's anti Africa narrative. While there is some cause for concern and rightly so, the ICC must take judicious steps to address criticisms levied against it; however, critics and African leaders branding of the ICC as an antiAfrica institution must not be the dispositive factor for African states withdrawal from the ICC's jurisdiction.

First, the ICC is hardly an institution that looks anti-African. ${ }^{93} 122$ countries are States Parties to the Rome Statute of the ICC. ${ }^{94}$ Out of the 122 state parties, 33 are African States, 18 are Asia-Pacific States, 18 are from Eastern Europe, 28 are from Latin American and Caribbean States, and 25 are from Western European and other States. ${ }^{95}$ African played a tremendous role in the establishment of the ICC, only 11 African countries have not signed the Rome Statute while 33 have ratified its provisions, making Africa the most heavily represented region in its membership. ${ }^{96}$ To date, only Burundi has withdrawn from the ICC, with few others threatening to leave the ICC if reforms are made. It is both common sense and logical that if the ICC was truly an anti-Africa institution, that majority, if not all of the continent's state parties would have left the ICC's jurisdiction by now. This is not the case.

Second, all the African cases before the ICC whether cases on preliminary examinations or situations under investigation were brought there legally. Of the twelve cases under investigation at the ICC, ten are from the African continent, and the remaining two are from Europe and Asia respectively. ${ }^{97}$ According to its mandate set out in the Rome Statute, the ICC's jurisdiction is limited to war crimes, crimes against humanity, genocide and crimes of aggression. ${ }^{98} \mathrm{The}$ ICC 's broad jurisdictional reach has limitations, however, African critics of the ICC have not made this argumentbecause all the cases before the ICC are legally under its jurisdiction. The ICC may only exercise jurisdiction if the accused is a nation or a state party; or the crime took place on the territory of a state party; or the UNSC has referred the situation to the prosecutor, irrespective of the nationality of the perpetrator or the location of the crime. ${ }^{99}$

Generally, the jurisdiction of the Court shall be limited to the most serious crimes of concern to the international community as a whole. ${ }^{100}$ The African cases before the ICC are all cases that affects and concerns the international community as a whole. African critics, especially its leaders have accused the court of failing to deliver justice elsewhere where similar crimes and atrocities are taken place. While this contention has some merit, however, it is however implausible for the ICC to act, especially when the UNSC failed to refer situations to the ICC. The reason is that many of these countries where the situation of concerns is at simply do not fall within the ICC's jurisdiction. ${ }^{101}$ African critics of the ICC argued that this double standard creates a form a selective justice and conspiracy against the continent. While

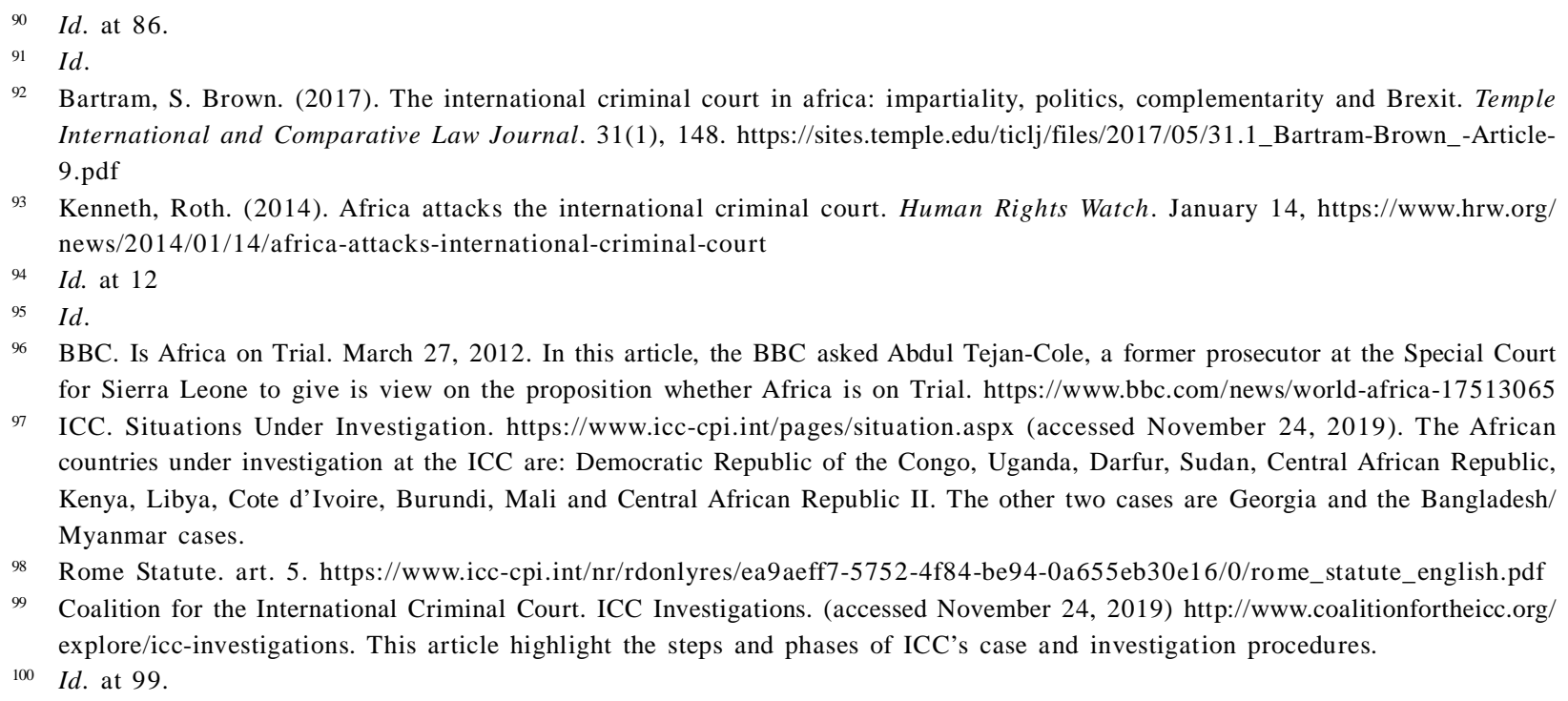

96 BBC. Is Africa on Trial. March 27, 2012. In this article, the BBC asked Abdul Tejan-Cole, a former prosecutor at the Special Court for Sierra Leone to give is view on the proposition whether Africa is on Trial. https://www.bbc.com/news/world-africa-17513065

97 ICC. Situations Under Investigation. https://www.icc-cpi.int/pages/situation.aspx (accessed November 24, 2019). The African countries under investigation at the ICC are: Democratic Republic of the Congo, Uganda, Darfur, Sudan, Central African Republic, Kenya, Libya, Cote d'Ivoire, Burundi, Mali and Central African Republic II. The other two cases are Georgia and the Bangladesh/ Myanmar cases.

98 Rome Statute. art. 5. https://www.icc-cpi.int/nr/rdonlyres/ea9aeff7-5752-4f84-be94-0a655eb30e16/0/rome_statute_english.pdf

99 Coalition for the International Criminal Court. ICC Investigations. (accessed November 24, 2019) http://www.coalitionfortheicc.org/ explore/icc-investigations. This article highlight the steps and phases of ICC's case and investigation procedures.

$100 \quad$ Id. at 99.

$101 \quad I d$. at 37. 
it is true that the ICC can be lambasted for inconsistent case selection, there is not a single case before the Court that one could dismiss as being frivolous or vexatious. ${ }^{102}$

Third, Africa's selective justice criticisms of the ICC's rest on an incorrect interpretation of the ICC's investigation and evidence gathering procedures. Cases at the ICC can be initiated in one of three ways: first, by a state who is a party to the Rome Statute (by nationality or territoriality); second, by referral from the UNSC, and third by the ICC Prosecutor choosing to investigate a certain case in proprio motu. ${ }^{103}$ To date, there has been two cases where the UNSC have made referral to investigate (Sudan and Libya) and three cases (Burundi, Kenya, and Ivory Coast) where the ICC Prosecutor has initiated its powers in proprio motu to investigate and prosecute countries from crimes human rights violations and other impunities. ${ }^{104}$ It is important to highlight that there is great support from other African countries for referrals made the ICC and UNSC. The Democratic Republic of Congo, Benin and Tanzania voted in favor of the UNSC referral of the Darfur situation to the ICC; while South Africa, Gabon and Nigeria voted in favor of the UNSC referral of the Libya situation to the ICC. ${ }^{105}$ Similarly, Ivory Coast accepted the jurisdiction of the ICC and undertook to cooperate with the ICC, ${ }^{106}$ while Kenya's then president, President Kibaki and then Prime Minister, Odinga pledged support to the Prosecutor's independent decision to open investigation into crimes in Kenya proprio motu. ${ }^{107}$ Most recently, Mali referred to the ICC the crimes occurring on its own territory since 2012 and this was supported by the Economic Community of Western African States (ECOWAS). ${ }^{108}$ Of the three ways of triggering the ICC's prosecutorial jurisdiction, African governments have made five self-referrals to the ICC, thus making the self-referral process the most used out of the ten current situations from Africa under the ICC's jurisdictions. ${ }^{109}$ The logic here is simple: African governments by referring its cases to the ICC shows without a doubt a strong belief in the role of the ICC on the continent. According to the Court's Prosecutor, Fatou Bensouda, "the high rate of referrals from Africa could just easily show that the leaders on the continent were taking their responsibilities to international justice seriously." 110 Also, the Prosecutor confirmed Africa's support of the ICC citing that "African states receive more than half of the Office of Prosecutor's total requests for cooperation and $70 \%$ of these requests are met with positive responses." 111 Similarly, scholars have posited a clear viewpoint of Africa's criticisms of the ICC. According to renowned international law scholar, Mahmoud Cherif Bassiouni in his submission to the Africa Question on the ICC Forum, he noted that "in short, the only situations in which the Court's jurisdiction is truly controversial are those that have been referred by the United Nation Security Council." 112 Mr. Bassiouni further stated that "in fact, African political leaders have only objected specifically to these two (Sudan and Libya), and therefore the argument should perhaps be refocused on the role of the Security Council, and not the ICC in African conflicts, as well as the Council's lack of action elsewhere." 113

Fourth, and contrary to popular opinion, the ICC is not a court of first resort. ${ }^{114}$ The Rome Statute provides that if a state pursues a case, that case will be inadmissible before the ICC unless that state is "unwilling or unable" to genuinely prosecute the case. ${ }^{115}$ Entrenched in its statutes, namely the Rome Statute Article seventeen (17) is the principle of complementarity, which recognizes the importance of cooperation with national jurisdiction. ${ }^{116}$ In simple terms, the ICC can only exercise its jurisdiction where the state party of which the accused is a national or on whose soil

102 BBC. Is Africa on Trial? March 27, 2012. (last accessed on November 16, 2019). https://www.bbc.com/news/world-africa-17513065 This BBC article covered Abdul Tejan-Cole, a former prosecutor at the Special Court for Sierra Leone. He argued that Africa is not on trial and has not been put on trial at any given time of the ICC's existence.

103 Id. at 97 . Article 14 of the Rome Statute governs and grants a state party the powers to refer situations to the ICC for review. Article 15 of the Statute governs the second ICC's referral and investigate process that allows the OTP to initiate investigations on its own recognizance or proprio motu. This process required Article 18 of the Statute as a procedural safeguard and as a means to notify the receiving state of the process. The third referral process is trigged when UNSC by resolution refer cases the ICC. Article 13 (a) and (b) respectively govern this process.

104 Id. at 95

105 Id. at 99.

106 Id.

107 Id.

108 Id.

$109 I d$. at 100.

110 Id. at 94

111 Rorisang Lekalake and Stephen Buchanan-Clarke. Support for the International Criminal Court in Africa: Evidence from Kenya. Afrobarometer Policy Paper No.23. 1 - 18, (accessed November 24, 2019). https://afrobarometer.org/sites/default/files/publications/ Policy\%20papers/ab_r6_policypaperno23_kenya_anti_corruption.pdf

112 M. Cherif Bassiouni and Douglas Hansen. ICC Forum: The Inevitable Practice of the Office of the Prosecutor. (accessed November 24, 2019) https://iccforum.com/africa

$113 \quad I d$.

$114 \quad I d$. at 100 .

115 Id. at 93.

116 Rome Statute, art 17. 
the alleged crime was committed, is unable or unwilling to prosecute. ${ }^{117}$ But for the ICC's using one of its three means of referrals, most of the cases in African would not have been brought to the ICC willingly because African governments have been reluctant to prosecute. A perfect example of this failure and unwillingness to prosecute showcased itself in Kenya. In the case of Kenya, even though Kofi Annan and others supported a "Kenyan-owned and Kenyan-led process", the country's parliament failed to pass the necessary laws to create a special tribunal thus giving the ICC jurisdiction. ${ }^{118}$ Based on these perspectives and the role of the complementarity principle supposed to play in linking the ICC and the national jurisdiction, it is clear that the African governments themselves should shoulder the blame for failing to act and prosecute cases in their jurisdiction-when in fact they have first resort over the cases. The complementarity provision of the Rome Statute means that the ICC cannot automatically usurp jurisdiction from states or steamroll local considerations or needs. ${ }^{119}$ In other words, the ICC is predicated on the belief that "it is the duty of every State to exercise its criminal jurisdiction over those responsible for international crimes." ${ }^{120}$ Not only does this mean that the primary responsibility for the enforcement of international criminal law rests with states, but also that domestic prosecution is preferable to the intervention of the ICC. ${ }^{121}$

Evident in the Kenya example above, many African states before the ICC has failed woefully in providing justice to victims or address the issues occurring in their respective states. African government's failure to act have resulted and prompted the ICC to take jurisdiction of the cases. In most cases, African countries lack proper social and judicial structures and means to prosecute. Many African countries will be unable to prosecute even if they want to because their judiciaries lack the capacity to prosecute the crimes in the Rome Statute and because their parliaments have failed to domesticate the relevant laws. ${ }^{122}$ This is Africa's weakness, not that of the ICC. The fact that the ICC has to be called upon to deal with legal issues that ought to be handled effectively by African governments is a sign of African states' collective failure to properly govern themselves and administer justice fairly and timely. ${ }^{123}$ In contrast, African critics of the ICC has taken a regional and geographical argument, citing to the continent's status as been poor and venerable. The need for greater resources is vital for the court — and the ICC opening preliminary examinations and investigations in parts of Asia and Europe has helped mitigate, if not deduce Africa's claims for selective justice. ${ }^{124}$ But there is not a case before the court that critics can honestly argue should not be there. ${ }^{125}$ Abdul Tejan-Cole, a former prosecutor at the Special Court for Sierra Leone and international criminal law expert cleverly react to this claim citing that "they might all be African but they are also all legitimate." ${ }^{26} \mathrm{He}$ went out to say, "it is farcical; that we can equate the trial of 25 accused with the trial of an entire continent." 127

Sixth, rogue African leaders not the common people of Africa are the ones criticizing the ICC. As such, it is relevant to distinguish where the criticism of the ICC is emanating from. African leaders with dubious and scrupulous motives are the ones leading the charge against the ICC anti-African narrative. What is to be clear is that before the ICC began investigating African presidents, it had broad support from African governments. ${ }^{128}$ Similarly, it is important to note that the misgivings voiced about the ICC are rarely those of victims. ${ }^{129}$ Several examples of victims' outcry for justice will suffice. Victims of the alleged atrocities of Chad's former President, Hissene Habre, have for several years been lobbying the Senegalese government to ensure that justice is done-but to little avail. ${ }^{130} \mathrm{Also}$, it is not the view of the victims of mass crimes — such as the 129 who participated in the Lubanga trial—who know that their national courts are invariably unable or unwilling to prosecute. ${ }^{131}$ Similar unwillingness to prosecute crimes and other human rights violations took place in Kenya. According to a report from Amnesty international on the Kenya situation, "the government's continued failure to properly investigate crimes committed during the 2007-2008 post-election violence and to provide justice and reparation for its victims is having a devastating impact on their lives and livelihoods." 132

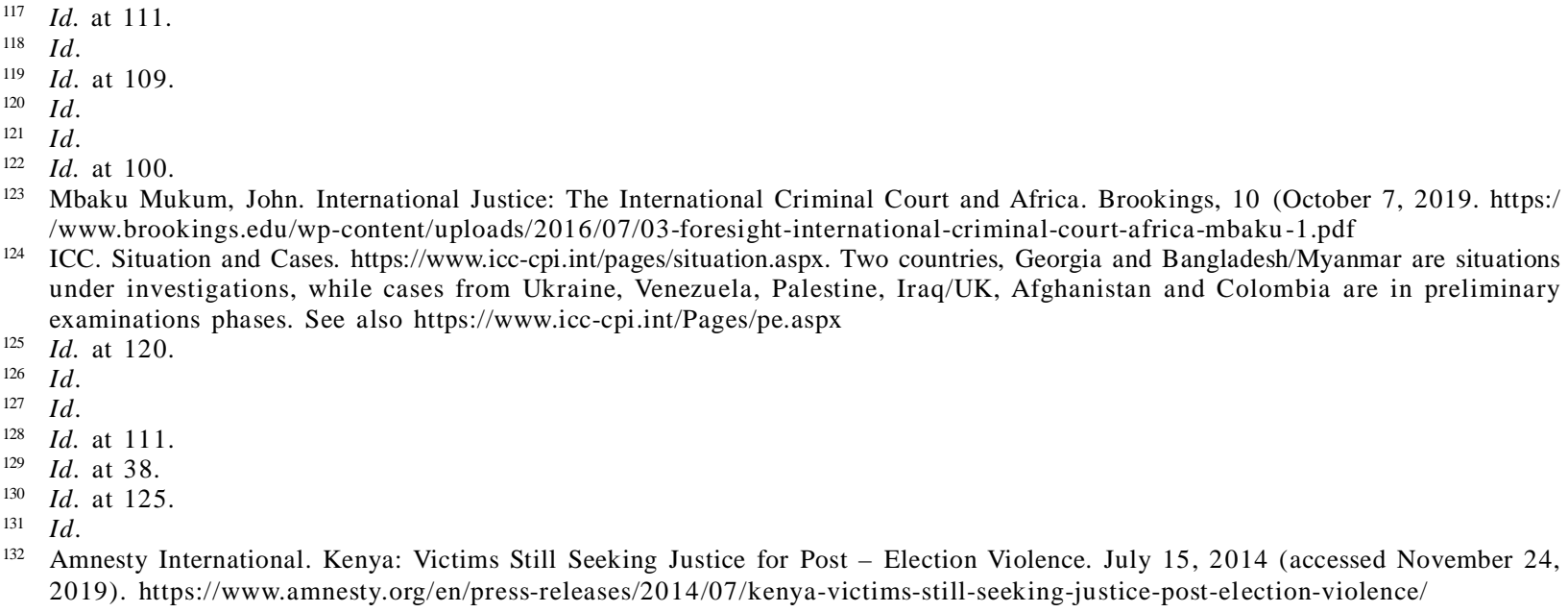


Also in Kenya, despite the harsh criticisms levied against the ICC by Kenyatta and Ruto, the ICC is still seen as a force for good on the continent. An Afrobarometer survey show support for ICC prosecutions of Kenyan political figures is relatively high: $61 \%$ of Kenyans believe that the cases are an important tool for fighting impunity in the country, $[\mathrm{m}]$ ore than half believe that the court is an impartial institution $(55 \%)$ and $(55 \%)$ reject the notion of withdrawing from the ICC. ${ }^{134} 3$

Likewise, the ICC maintains broad public support from citizens on the continent. Claire Felter, a senior fellow for Africa Studies at the Council on Foreign Relations (CFR) writes that "the opposition of many African leaders to the ICC is not necessarily aligned with the desire of many Africans for fairness and accountability." 134 In opposition of the ICC' role on the continent, African statesmen, the AU and some publists have expressed great discomfort with the ICC. ${ }^{135}$ It is this version of events that has increasingly come to dominate the debate in Africa with political leaders past and present publicly accusing the court of anti-African bias and of persecuting the continent through its prosecutions. ${ }^{136}$ Regardless of African leaders' sentiments against the ICC, the ICC must focus on the common people, namely victims of crimes and the general citizens on the continent. This approach must be amplified as it is clear that "ordinary Africans are not complaining because many have suffered at the hands of the perpetrators of mass crimes - and know that there is little chance that they will see justice done without international tribunals like the ICC."137

\section{Motion for continued constructive engagement}

The people of Africa and the African continent matter to the ICC. In fact, it would be foolhardy to suggest otherwise. Equally, it will be a colossal mistake for the ICC and the international community to ignore Africa's heightened calls for reforms of the ICC. Africa and the ICC can only remedy their already strained relationship by dialogue and engagement.

First, the ICC must not appear to be anti-African, when in all intent and purposes it is not. To many Africans critics of the ICC, most see the ICC as an extension of colonialism and are constantly left reeling of the Court's unbalance actions on the continent. The ICC is not a perfect institution nor are its investigation proceedings. Even today, the ICC remains very much a work-in-progress, ${ }^{138}$ and acceptance of this reality is key, while work to reform the institution continue from within.

Second, the ICC primary focus must be on the victims of crimes and atrocities committed on the African continent. By focusing on the victims, ICC will be having a direct impact on justice in the continent as well as give victims a platform to tell their stories of survival. ${ }^{139}$ In simple terms, "[j] ustice for victims of genocide and other war crimes is achieved when all the alleged war criminal is in the dock." Crimes as the ones committed on the continent constitute a violation of international law and presents an ongoing threat to peace and national development in countries affected by war or armed conflicts. Renowned European and International law expert, Guénaël Mettraux endorsed this viewpoint in his volume one collection on Genocide stating that "genocide and war crimes constitute violations of international law". ${ }^{140}$ While heads of state, individually and collectively, through the AU or UN have ample opportunity to express their concerns and extensive publicity is given to their views, [however], it is the complex and multifaceted voices of the victims that needs greater attention ${ }^{141}$. Evidently, "if there are no ICC trials of alleged war criminals, there will be no accurate memory." "142 The ICC can achieve this objective in three ways. First, give more voice and publicity to victims. The ICC was created to prevent impunity and give justice to victims of these crimes and atrocities, so the ICC being victim-focused will only help not hurt its credibility and legitimacy. Second, the ICC can directly engage the victims of these crimes by providing pathways for their stories to be heard. In other words, victims' roles in the process of prosecution from preliminary examinations to witness gathering to consultation about the approaches about the sources of evidentiary elements to be used in trying the perpetrator (s) of the case are relevant. It is therefore necessary to engage with victims and hold conversations regarding approaches to justice. ${ }^{143}$ Third, the ICC can make victims reparations

33 Id. at 112.

134 Claire Felter. The Role of the International Criminal Court. Council of Foreign Relations, May 30 2019. https://www.cfr.org/ backgrounder/role-international-criminal-court Claire Felter quoted Michael D Gavin, also a fellow at the CFR.

135 Id. at 75.

136 Id. at 129.

137 Id.

138 Id. at 116.

139 Guénaël Mettraux. International Crimes: Law and Practice. Volume 1: Genocide. Oxford University Press, 30. (2019. This chapter examines the common themes and overlapping elements between genocide and war crimes. This chapter also went on to highlight the differences of the two and they can be identified.

140 Howard, Ball. (1999). Prosecuting War Crimes and Genocide. University Press of Kansas, 224.

141 Id. at 130.

142 Id. at 141

143 Id. 
a necessity for victims, especially in cases where the perpetrators have the means, or their source of wealth was attained in furtherance or in conspiracy of the alleged crimes and atrocities. The process of reparations does not only give a semblance of justice for the physical, economic or psychological harm suffered by victims, they also potentially can serve as a deterrent to perpetrators of these crimes. Reparations are necessary in order to repair the damage to the reputation and honor of the victims and their next of kin, and in order to avoid repetition." ${ }^{144}$ Reparations method can only be further advanced to help and provide victims with much needed support as they seek justice for the wrongs against them. To do this effectively, actors such as the "ICC Office of Prosecution (OTP), as well as the lawyers, civil societies, activists, survivors and people working with them, in order to establish what victims are truly seeking." 145

Third, the ICC must be consistent in its use of the complementarity principle in member states jurisdictions. Complementarity governs the relationship between the ICC and national legal orders. ${ }^{146}$ Under this principle, the ICC could actually and genuinely cede some of its reach in evidence gathering and pre-trial preparations to the national courts in the Africa states they occurred. By doing this, the ICC will not diminish its jurisdictional capacity but rather strengthen it on the continent. One solution is for African states to commit to prosecuting international crimes in their domestic courts, rather than engaging in a prolonged confrontation with the ICC. ${ }^{147}$ This method of compromise and showcase of partnership, which most Africans expect to have with the court will improve trust between national prosecutors and their counterparts at the ICC.

Fourth, ICC must provide support and resources to help in the advancement of regional courts in Africa. Due in part to the fact ICC's resources in terms of budget and staff are limited, the OTP need states (as well as non-state actors) to bolster its investigations by allowing investigations to take place on their territory or by volunteering evidence for specific cases. ${ }^{148}$ Africa has made significant strides in creating regional courts to be responsible for mass violations of human rights and other crimes. An additional, complementary mechanism that contributes to the AU's peace and security work is the creation of a criminal court within the African peace and security architecture. ${ }^{149}$ The ICC must partner with regional bodies on the continent to make this dream a reality. With this, however, caution should be exerted because said regional courts in Africa are still lacking in important ingredients before such courts can take up the responsibilities of an international courts. With challenges of incompetence and weak judicial systems, Africa is not yet ready to fully try its own international crimes cases on the continent.

Fifth, the ICC must engage with civil society groups and the common African community by educating them about the invaluable role of Court. Since most of the criticisms against the ICC is about anti-African bias, the ICC must work with regional parties to strengthen democratic institutions as well as avoid semblance of bias in its case selection. To do this effectively, citizens must be made aware via civil society organs of the role and structure of the ICC. Given these competing tensions, democratically elected governments should ensure that their citizens' interests are at the heart of any decisions regarding the implementation of international justice in their respective countries. Full representation of these interests requires both awareness of and responsiveness to public opinion on this issue. ${ }^{150}$ At present, little is known about citizens' preferences. ${ }^{151}$ As a result, it is vital to help the common people in Africa to understand the role of the ICC, its fallibility and its challenges - and no better tool exist for that than education done through sensitization campaigns and other educational themed event about the ICC.

Sixth, there is an urgent need for multifaceted cooperation between actors involved to remedy the relationship. This means encouraging everyone to come to the table and contribute to the process of reform of the ICC. Actors such the AU, the UN Security Council, African members and other state parties to the ICC must render a supporting hand to ensure the proper functioning of the ICC. Accordingly, the challenge is to build an international court that is able to respond fairly and credibly to the global, rather than a merely continental, demand for effective accountability and impartial justice. ${ }^{152}$

144 Conor, McCarthy. (2012). Reparations and victim support in the international criminal court. Cambridge Studies in International and Comparative Law, 182.

145 Id. at 142 .

146 Olympia Bekou. Complementarity Principle. Oxford Bibliographies. Accessed October 28 , $2019 . \quad$ https:// www.oxfordbibliographies.com/view/document/obo-9780199796953/obo-9780199796953-0071.xml

147 Id. at 136 .

$148 \quad I d$. at 85

149 Newsday. Why a regional criminal court for Africa is a good idea. October 2, 2019. (last accessed November 3, 2019). https:// www.newsday.co.zw/2019/10/why-a-regional-criminal-court-for-africa-is-a-good-idea/

$150 \quad I d$. at 112 .

151 Id.

152 Id. at 146 
Finally, reforming the ICC from within must be the ultimate of all parties involved. A tribunal's legacy contributes positively to its sociological legitimacy when important audiences perceive its work as highly valuable. ${ }^{153}$ States parties can offer this safeguard by advancing the ICC's morals and legitimacy in their home countries. However, perceptions of a tribunal's work may be more or less positive than the work itself merits for all of the many reasons that perceptions often fail to reflect reality, including, for instance, confirmation and implicit biases. ${ }^{154}$ This is true with the ICC. For the most part, the ICC has been left standing by state parties to defeat by itself the many criticisms levied at it, and this has negatively impacted the good work the Court. The ICC as we know in an imperfect institution, however, it needs to do more with its methods of investigation and Pre-Trial proceedings. The ICC can make amendments to some of its statutes and [a]mendments to the Rome Statute have been proposed on prior occasions. ${ }^{155}$ Constructive legal amendments could possibly be made to the Rome Statute to meet the demands of the states and international criminal justice as a whole. ${ }^{156}$ Another provision relevant to reforming the ICC is Article 122, which allows amendments of an institutional nature, including, for example, the service and required qualifications and nominations of judges. ${ }^{157}$ Implementing these recommendations will go a long way to bridging the gap between all parties involved and thus help in the ICC's quest for much needed reforms in its structure and performance.

\section{Conclusion}

The fact that only Africans have been charged before the ICC is bound to provoke cynicism. ${ }^{158}$ However, there is substantial evidence to support the charges that have been brought before the Court. ${ }^{159}$ Africa and ICC relationships have been strained for many years and [ $t$ ]here is a need for the continued relevance of the ICC, and African countries membership is quite important. ${ }^{160}$ Debate on the ICC's role in Africa has strayed from what matters most: ending impunity for perpetrators of gross human rights violations by providing access to justice and impartial adjudication for victims. ${ }^{161}$ The ICC was created to address the problem of impunity, and its officials should only work towards that end. To do less would encourage political second-guessing of every decision she makes. ${ }^{162}$ Instead of fighting impunity on the continent, attention has largely turned to ideological and geopolitical disputes. To remedy this, "it is important that powerful nations of the world become members so as to stop African leaders from feeling that the court was set up to victimize them." " 163 Everyone in society has a role to play in fighting and preventing heinous crimes and human rights violations whether they happen in Africa or elsewhere. The question is ICC unfairly or inappropriately targeting Africa is a salient one. Equally, are Africa's criticisms of the ICC a sound justification for why majority of the situations and cases under investigation or prosecution? Notably, answers to these questions may depend on the interpretation of the relevant provisions of the Rome Statute, views regarding the purpose and mandate of the ICC and a range of practical considerations. ${ }^{164}$

\section{Bibliography of sources}

Statues and Rules

1. Rome Statute of the International Criminal Court, adopted by the Security Council on 17 July 1998, U.N. doc A/ CONF.183/9(1998)

Cases

ICC

2. Prosecutor v Bemba (Warrant of Arrest) International Criminal Court, Pre-Trial Chamber III, Case No ICC-01/0501/08, 23 May 2008.

153 Milena Sterio, Michael P. Scharf. The Legacy of Ad Hoc Tribunals in International Criminal Law: Assessing the ICTY's and the ICTR's Most Significant Legal Accomplishments, 271 (2019).

$154 \quad I d$.

$155 \quad I d$. at 153 .

156 Id.

$157 \quad I d$. at 153 .

$158 \quad I d$. at 136

159 Id.

160 Taofik, Abiodun, Okunola. (2017). The continued relevance of the international criminal court in the contemporary international order. Global Journal of HUMAN-SOCIAL SCIENCE: H Interdisciplinary 17(3) Version (2017). (accessed November 2, 2019). https://globaljournals.org/GJHSS_Volume17/7-The-Continued-Relevance.pdf

161 Id. at 151.

162 Id. at 161

163 Id.

$164 \quad I d$. at 102 
3. Prosecutor v Bemba (Warrant of Arrest Replacing the Warrant of Arrest Issued on 23 May 2008. International Criminal Court, Pre- Trial Chamber III, Case No ICC-01/05-01/08, 10 June 2008.

4. Prosecutor v Ruto (Decision on the Prosecutor's Application for Summons to Appear) International Criminal Court, Pre-Trial Chamber II, Case No ICC-01/09-01/11, 8 March 2011

5. Prosecutor v Muthaura (Decision on the Prosecutor's Application for Summonses to Appear) International Criminal Court, Pre-Trial Chamber II, Case No ICC-01/09-02/11, 8 March 2011

6. Prosecutor v Muthaura (Prosecution Notification of Withdrawal of the Charges) International Criminal Court, Trial Chamber V, Case No ICC-01/09-02/11, 11 March 2013

7. Prosecutorv. Laurent Gbagbo and Charles Blé Goudé. International Criminal Court, Pre-Trial Chamber I, Case No ICC- ICC-02/11-01/15. (On 15 January 2019, Trial Chamber I, by majority, acquitted Mr. Laurent Gbagbo and Mr. Charles Blé Goudé from all charges of crimes against humanity allegedly committed in Côte d'Ivoire in 2010 and 2011).

8. Prosecutor v Simone Gbagbo (Warrant of Arrest) International Criminal Court, Pre-Trial Chamber III, Case No ICC-02/11-01/12, 29 February 2012.

9. Prosecutorv Gaddafi (Warrant of Arrest for Muammar Gaddafi) (International Criminal Court, Pre-Trial Chamber I, Case No ICC-01/11-01/11, 27 June 2011). The arrest warrant against Muammar Gaddafi was terminated on 22 November 2011 following his death.

10. Prosecutorv Lubanga (Warrant of Arrest) (International Criminal Court, Pre-Trial Chamber I, Case No ICC-01/0401/06, 10 February 2006);

11. Prosecutor $v$ Katanga (Decision on the Joinder of the Cases against Katanga and Chui) (International Criminal Court, Pre-Trial Chamber I, Case No ICC-01/04-01/07, 10 March 2008).

12. Prosecutorv Al Bashir (Second Warrant of Arrest) (International Criminal Court, Pre-Trial Chamber I, Case No ICC-02/05-01/09, 12 July 2010.

13. Prosecutor v Joseph Kony et al., (Amended Warrant of Arrest for Kony) (International Criminal Court, Pre-Trial Chamber II, Case No ICC-02/04-01/05, 27 September 2005)

14. Prosecutor v. William Samoei Ruto and Joshua Arap Sang, Decision on Defence Applications for Judgments of Acquittal, ICC-01/09-01/11 (April 5, 2016),

\section{Books}

15. Conor McCarthy. Reparations and Victim Support in the International Criminal Court. Cambridge University Press. 182 (2012)

16. David M. Crane, Leilan N. Sadat and Michael Scharf. The Founder: Four Pioneering Individuals Who Launched the First Modern-Era International Criminal Tribunals. Cambridge University Press, 32-33 (2018).

17. Guénaël Mettraux. International Crimes: Law and Practice. Volume 1: Genocide. Oxford University Press, 30-31 (2019).

18. Howard Ball. Prosecuting War Crimes and Genocide. University Press of Kansas, 224 -225 (1999).

19. Mark Kersten. Justice in Conflict: The Effects of the International Criminal Court's Intervention on Ending Wars and Building Peace. Oxford University Press, 167 -193 (2016).

20. Milena Sterio and Michael P. Scharf. The Legacy of Ad Hoc Tribunals in International Criminal Law: Assessing the ICTY's and the ICTR's Most Significant Legal Accomplishments. Cambridge University Press; Reprint edition, 271-72 (February 21, 2019)

\section{Law Review and Articles}

21. Abreha Mesele. International Criminal Court and African Union: Selective Justice? Abyssinia Law, June 17, 2019

22. Abdul Tejan-Cole. Let the World Tribunal Do What Local Courts Cannot. The New York Times. March 4, 2013. (accessed November 16, 2019).

23. African Centre for Justice and Peace Studies, Journalist Madiha Abdalla Convicted of Defamation by Press and Publications Court. (accessed November 22, 2019). 
24. Allan Ngari. The Real Problem behind South Africa's refusal to arrest al-Bashir. Institute for Security Studies. July 10, 2017.

25. Amnesty International. Kenya: Victims Still Seeking Justice for Post - Election Violence. (2014).

26. Bartram S. Brown. The International Criminal Court in Africa: Impartiality, Politics, Complementarity and Brexit. Temple International and Comparative Law Journal, Vol 31 (1), 145 - 177 (2017).

27. BBC. Burundi leaves International Criminal Court amid Row. October 2, 2017.

28. BBC. Is Africa on Trial? March 27, 2012.

29. Business Day. Government Prepares to Quit the ICC and Introduce an Alternative System. November 3, 2019.

30. Brendon J. Cannon, Dominic R. Pkalya, Bosire Maragia. The International Criminal Court and Africa: Contextualizing the Anti-ICC Narrative. Africa Journal of International Criminal Justice, Issue 1-2, 7 -24, (2016).

31. Christine Bjork and Juanita Goebertus. Complementarity in Action: The Role of Civil Society and the ICC in Rule of Law Strengthening in Kenya. Yale Human Rights and Development Law Journal 14(1), 205-229 (2011).

32. CNN. International Criminal Court Fast Facts. CNN Editorial Research. (November 11, 2019).

33. Claire Felter. The Role of the International Criminal Court. Council of Foreign Relations. May 302019.

34. Dickens Olewe. How Kenyatta led Africa's Opposition to the ICC. BBC. (October 24, 2016).

35. Gabrielle Lynch and Misa Zgonec-Rozej. The ICC Intervention in Kenya. Chatham House Programme. Paper AFP/ILP 1, 9 - 12. (February 2013

36. Rowland J V. Cole. Africa's Relationship with the International Criminal Court: More Political than Legal. Melbourne Journal of International Law, Vol.14: 670 - 692, (2014).

37. Karen Allen. Is This the End for the International Criminal Court? BBC. October 24, 2016.

38. Kenneth, Roth. Africa Attacks the International Criminal Court. Human Rights Watch, January 14, 2014.

39. Laurence R. Helfer, Anne E. Showalter. Opposing International Justice: Kenya's Integrated Backlash Strategy Against the ICC. iCourts Working Paper Series, No. 83, (2017).

40. Mark Kersten. Building Bridges and Reaching Compromise: Constructive Engagement in the Africa - ICC Relationship. Wayamo Foundation. Wayamo Foundation Policy Report 5 - 25, (2018).

41. Mattia Cacciatori. When Kings Are Criminals: Lessons from ICC Prosecutions of African Presidents. International Journal of Transitional Justice, Volume 12, Issue 3, 386 - 406, (2018).

42. Newsday. Why a regional criminal court for Africa is a good idea. (October 2, 2019).

43. Somini Sengupta. As 3 African Nations Vow to Exit, International Court Faces its own Trial. The New York Times. (October 26, 2016).

44. Statement of the Prosecutor of the International Criminal Court, Fatou Bensouda, on the Withdrawal of Charges Against Mr. Uhuru Muigai Kenyatta (Dec. 5, 2014).

45. Taofik Abiodun, Okunola. The Continued Relevance of the International Criminal Court in the Contemporary International Order. Global Journal of HUMAN-SOCIAL SCIENCE: H Interdisciplinary Volume 17 Issue 3 Version (2017).

46. Thierry Cruvellier. The ICC, Out of Africa. The New York Times, November 6, 2016. https://www.icc-cpi.int/Pages/ item.aspx?name=Adjourn-Kenyatta05-12-2014

\section{Other}

47. Olympia Bekou. Complementarity Principle. Oxford Bibliographies. Accessed October 28, 2019. https:// www.oxfordbibliographies.com/view/document/obo-9780199796953/obo-9780199796953-0071.xml

\section{Miscellaneous}

48. African Union. Communique of the 142nd Meeting of the Peace and Security Council. PSC/MIN/Comm (CXLII) July 21, 2008. (accessed November 22, 2019) http://www.iccnow.org/documents/AU_142-communique-eng.pdf.

49. African Union. Extraordinary Session of the Assembly of the African Union: Decisions and Declarations. October 12, 2013, (accessed November 22, 2019). http://www.iccnow.org/documents/Ext_Assembly_AU_Dec_Decl_ 12Oct2013.pdf 
50. Coalition for the International Criminal Court. ICC Investigations. (accessed November 24, 2019) http:// www.coalitionfortheicc.org/explore/icc-investigations

51. Fatou Bensouda. Africa Question: Is the (ICC (International Criminal Court)) Targeting Africa Inappropriately? ICC Forum. (accessed November 22, 2019), https://iccforum.com/africa

52. Hanibal Goitom. The International Criminal Court and Africa. Library of Congress Blogs. (November 23, 2016)

53. ICC. The States Parties to the Rome Statute. (November 10, 2019) https://asp.icc-cpi.int/en_menus/asp/ states\%20parties/pages/the $\% 20$ states $\% 20$ parties $\% 20$ to $\% 20$ the $\% 20$ rome $\% 20$ statute.aspx

54. ICC. Situation and Cases. November 3, 2019. https://www.cfr.org/backgrounder/role-international-criminal-court

55. ICC. Situations Under Investigation. https://www.icc-cpi.int/pages/situation.aspx (accessed November 24, 2019).

56. ICC. Al-Bashir case: ICC Pre-Trial Chamber II decides not to refer South Africa's non-cooperation to the ASP or the UNSC. July 6, 2017. https://www.icc-cpi.int/Pages/item.aspx?name=pr1320

57. Margaret M. deGuzman. ICC Forum. Africa Question. Is the ICC (International Criminal Court) Targeting Africa Inappropriately? (accessed November 24, 2019). https://iccforum.com/africa\#deGuzman

58. M. Cherif Bassiouni and Douglas Hansen. ICC Forum: The Inevitable Practice of the Office of the Prosecutor. (accessed November 24, 2019) https://iccforum.com/africa

59. Rorisang Lekalake and Stephen Buchanan-Clarke. Support for the International Criminal Court in Africa: Evidence from Kenya. Afrobarometer Policy Paper No.23, 1 - 18 (2019). https://afrobarometer.org/sites/default/ files/publications/Policy\%20papers/ab_r6_policypaperno23_kenya_anti_corruption.pdf 